\title{
Front Matter: Volume 10440
}

, "Front Matter: Volume 10440," Proc. SPIE 10440, Optical Materials and Biomaterials in Security and Defence Systems Technology XIV, 1044001 (13 October 2017); doi: 10.1117/12.2302599

SPIE. Event: SPIE Security + Defence, 2017, Warsaw, Poland 


\title{
Optical Materials and Biomaterials in Security and Defence Systems Technology XIV
}

\author{
Roberto Zamboni \\ François Kajzar \\ Attila A. Szep \\ Katarzyna Matczyszyn \\ Editors
}

11-12 September 2017

Warsaw, Poland

Sponsored by

SPIE

Cooperating Organisations

CENSIS: Innovation Centre for Sensor \& Imaging Systems (United Kingdom)

Polish Technological Platform on Photonics (Poland)

MIRPHAB (France)

Photonics Society of Poland (Poland)

Cranfield University (United Kingdom)

Published by

SPIE 
The papers in this volume were part of the technical conference cited on the cover and title page. Papers were selected and subject to review by the editors and conference program committee. Some conference presentations may not be available for publication. Additional papers and presentation recordings may be available online in the SPIE Digital Library at SPIEDigitalLibrary.org.

The papers reflect the work and thoughts of the authors and are published herein as submitted. The publisher is not responsible for the validity of the information or for any outcomes resulting from reliance thereon.

Please use the following format to cite material from these proceedings:

Author(s), "Title of Paper," in Optical Materials and Biomaterials in Security and Defence Systems Technology XIV, edited by Roberto Zamboni, François Kajzar, Attila A. Szep, Katarzyna Matczyszyn, Proceedings of SPIE Vol. 10440 (SPIE, Bellingham, WA, 2017) Seven-digit Article CID Number.

ISSN: 0277-786X

ISSN: 1996-756X (electronic)

ISBN: 9781510613447

ISBN: 9781510613454 (electronic)

Published by

SPIE

P.O. Box 10, Bellingham, Washington 98227-0010 USA

Telephone +1 3606763290 (Pacific Time) · Fax +1 3606471445

SPIE.org

Copyright (C) 2017, Society of Photo-Optical Instrumentation Engineers.

Copying of material in this book for internal or personal use, or for the internal or personal use of specific clients, beyond the fair use provisions granted by the U.S. Copyright Law is authorized by SPIE subject to payment of copying fees. The Transactional Reporting Service base fee for this volume is $\$ 18.00$ per article (or portion thereof), which should be paid directly to the Copyright Clearance Center (CCC), 222 Rosewood Drive, Danvers, MA 01923. Payment may also be made electronically through CCC Online at copyright.com. Other copying for republication, resale, advertising or promotion, or any form of systematic or multiple reproduction of any material in this book is prohibited except with permission in writing from the publisher. The CCC fee code is 0277$786 \mathrm{X} / 17 / \$ 18.00$

Printed in the United States of America.

Publication of record for individual papers is online in the SPIE Digital Library.

\section{SPIE. DIGITAL}

Paper Numbering: Proceedings of SPIE follow an e-First publication model. A unique citation identifier (CID) number is assigned to each article at the time of publication. Utilization of CIDs allows articles to be fully citable as soon as they are published online, and connects the same identifier to all online and print versions of the publication. SPIE uses a seven-digit CID article numbering system structured as follows:

- The first five digits correspond to the SPIE volume number.

- The last two digits indicate publication order within the volume using a Base 36 numbering system employing both numerals and letters. These two-number sets start with $00,01,02,03$, 04, 05, 06, 07, 08, 09, 0A, OB ... 0Z, followed by 10-1Z, 20-2Z, etc. The CID Number appears on each page of the manuscript. 


\title{
Contents
}

\author{
$\checkmark$ Authors \\ vii Conference Committee
}

\section{NANOSYSTEMS AND IMAGING}

1044004 Analysis of deformation of aluminum plates under the influence of nano- and microsecond laser pulses (Invited Paper) [10440-3]

\section{LIGHT CONTROL}

1044005 Surface relief gratings: experiments, physical scenarios, and photoinduced (anomalous) dynamics of functionalized polymer chains (Invited Paper) [10440-4]

1044006 Induced circular dichroism and laser action of hemicyanine dyes coupled to DNA and DNA-complex (Invited Paper) [10440-5]

1044007 LIBS spectra of multi-component Al, Fe, Cu alloys and composite materials used for selected elements of armament and munition [10440-6]

\section{APPLICATIONS}

10440 OC Optical and photochemical properties of diarylethylenes [10440-11]

\section{POSTER SESSION}

10440 OD Analyzing of chromaticity temperature of novel bulb composed of PDMS and phosphor [10440-14]

10440 OE Fiber optic sensor for monitoring a density of road traffic [10440-15]

$10440 \mathrm{OF}$ Analysis of the influence location of the fiber optic sensor on the measurement and determination the heart rate of the human body [10440-16]

10440 OG Characterization and visual illustration of the consequences motion of human body for the determination of heart rate [10440-17]

$10440 \mathrm{OH}$ Analysis of non-invasive FBG sensor for monitoring patient vital signs during MRI [10440-18]

$10440 \mathrm{Ol}$ The methodology of preparing the end faces of cylindrical waveguide of polydimethylsiloxane [10440-19]

10440 0J Analyzing of using PDMS polymer as the sensors of the pressure or weight [10440-21] 
10440 OK Noninvasive encapsulated fiber optic probes for interferometric measurement [10440-22]

$10440 \mathrm{OL}$ Analysis of creating an innovative micro-lens made of polydimethylsiloxane polymer on the end of the optical fibers [10440-23]

10440 OM Device for the alternative option of temperature measurement [10440-24]

10440 ON Hybrid optical security system using photonic crystals and MEMS devices [10440-25]

1044000 Fiber optic sensor system for entrance areas monitoring [10440-26]

10440 OP Bragg grating sensors for the monitoring load of production press machines [10440-27]

$10440 \mathrm{OQ}$ Monitoring of the structural loads of tunnels using a distributed optical system BOTDR [10440-28]

10440 OR Monitoring system of hydraulic lifting device based on the fiber optic sensors [10440-29]

10440 OS Processing of fetal heart rate through non-invasive adaptive system based on recursive least squares algorithm [10440-30]

$10440 \mathrm{OU}$ Analysis of the bending radius of the cylindrical waveguide of polydimethylsiloxane for the purpose of lighting [10440-20]

10440 OV Analysis of the use of fiber optic technology for the monitoring heart rate of the pregnant and fetus [10440-12]

10440 OW Fiber optic sensor based on Mach-Zehnder interferometer for securing entrance areas of buildings [10440-13] 


\section{Authors}

Numbers in the index correspond to the last two digits of the seven-digit citation identifier (CID) article numbering system used in Proceedings of SPIE. The first five digits reflect the volume number. Base 36 numbering is employed for the last two digits and indicates the order of articles within the volume. Numbers start with 00, 01, 02, 03, 04, 05, 06, 07, 08, 09, OA, OB...0Z, followed by 10-12, 20-2Z, etc.

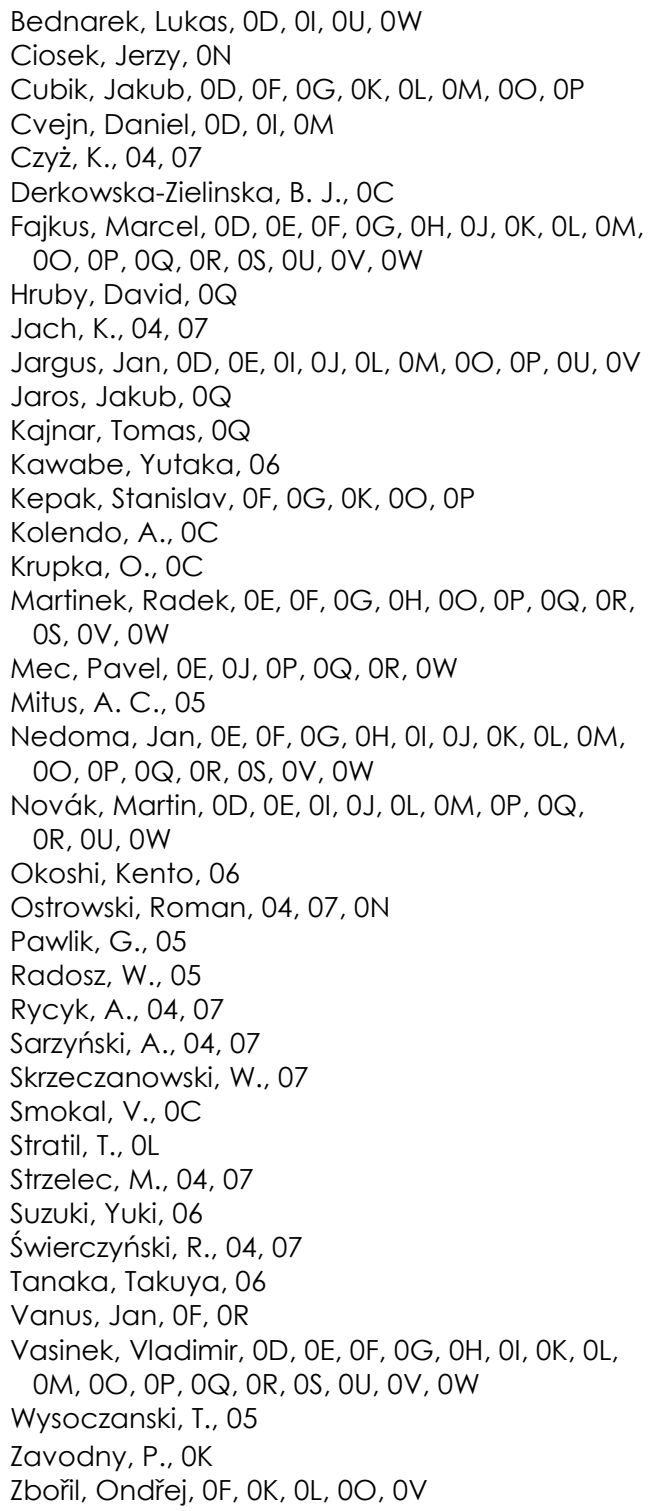


Proc. of SPIE Vol. $104401044001-6$

Downloaded From: https://www.spiedigitallibrary.org/conference-proceedings-of-spie on 26 Apr 2023 Terms of Use: https://www.spiedigitallibrary.org/terms-of-use 


\section{Conference Committee}

Symposium Chair

Ric Schleijpen, TNO Defence, Security and Safety (Netherlands)

Symposium Co-chairs

Karin U. Stein, Fraunhofer Institute of Optoronics System Technologies and Image Exploitation IOSB (Germany)

Jan K. Jabczyński, Military University of Technology (Poland)

Conference Chairs

Roberto Zamboni, Istituto per la Sintesi Organica e la Fotoreattività (Italy)

François Kajzar, University Politehnica of Bucharest (Romania)

Attila A. Szep, Air Force Research Laboratory (United States)

Katarzyna Matczyszyn, Wroclaw University of Technology (Poland)

Conference Programme Committee

Chantal Andraud, Ecole Normale Supérieure de Lyon (France)

André-Jean Attias, Université Pierre et Marie Curie (France)

Carrie M. Bartsch, Air Force Research Laboratory (United States)

Werner J. Blau, Trinity College Dublin (Ireland)

Fabrice Charra, Commissariat à l'Énergie Atomique (France)

Larry R. Dalton, University of Washington (United States)

Beata J. Derkowska, Torun University (Poland)

Manfred Eich, Technische Universität Hamburg-Harburg (Germany)

Patrick Feneyrou, Thales Research \& Technology (France)

Barrett Flake, Consultant (United Kingdom)

James G. Grote, Air Force Research Laboratory (United States)

Emily M. Heckman, Air Force Research Laboratory (United States)

Charles Y. C. Lee, Air Force Office of Scientific Research

(United States)

Antoni C. Mitus, Wroclaw University of Technology (Poland)

Jaroslaw Mysliwiec, Wroclaw University of Technology (Poland)

Jacek Niziol, AGH University of Science and Technology (Poland)

Robert L. Nelson, Air Force Research Laboratory (United States)

Yoshiko Okada-Shudo, The University of Electro-Communications

(Japan)

Fahima Ouchen, Air Force Research Laboratory (United States) 
Agnieszka Pawlicka, Instituto de Química de São Carlos (Brazil) Luana Persano, Istituto Nanoscienze (Italy) Ullrich Pietsch, Universität Siegen (Germany)

lleana Rau, University Politehnica of Bucharest (Romania)

Ifor D. W. Samuel, University of St. Andrews (United Kingdom)

Marina Saphiannikova Grenzer, Leibniz-Institut für Polymerforschung Dresdene e.V. (Germany)

Niyazi Serdar Sariciftci, Johannes Kepler University Linz (Austria)

Renato Seeber, Universitá degli Studi di Modena e Reggio Emilia (Italy)

Kenneth D. Singer, Case Western Reserve University (United States)

\section{Session Chairs}

$1 \quad$ Nanosystems and Imaging

Roberto Zamboni, Istituto per la Sintesi Organica e la Fotoreattività (Italy)

2 Light Control

Katarzyna Matczyszyn, Wroclaw University of Science and Technology (Poland)

3 Light Emission and Action

Attila Szep, Air Force Research Laboratory (United States)

4 Applications

François Kajzar, University Politehnica of Bucharest (Romania) 